\title{
ANALISIS PENYAJIAN PANDUAN PEMBELAJARAN LITERASI SAINS DALAM BUKU TEMATIK TERPADU KELAS IV KURIKULUM 2013
}

\author{
Ai Hayati Rahayu \\ Prodi PGSD STKIP Sebelas April Sumedang \\ Jl. Anggrek Situ No. 19 Sumedang \\ Email: ahayati75@gmail.com
}

\begin{abstract}
This study aims at determining the extent to which aspects of scientific literacy that consist of science as a body knowledge, science as the way of investigating, science as the way of thinking, and interaction among of science technology and society presented in the teacher book. The source of research data is an integrated thematic teacher book grade IV theme 3 concerned about the living creatures. The research study uses descriptive analysis to describe the aspects of scientific literacy. The analysis uses instruments that adopted from Chiapetta, Sethna and Filman in Padayache. The result of the analysis showed that two important findings: 1) aspect of science as a body of knowledge having the highest percentage of the three aspects; 2) Not all of indicators of the aspects found in the teacher book guide. Keywords: teacher books, scientific literacy, quantitative analysis, curriculum 2013.
\end{abstract}

ABSTRAK

Penelitian ini bertujuan untuk mengetahui sejauh mana aspek literasi sains yang terdiri dari ilmu sebagai body knowledge, ilmu pengetahuan sebagai cara menyelidiki, ilmu pengetahuan sebagai cara berpikir, dan interaksi antara teknologi sains dan masyarakat yang disajikan dalam buku guru. Sumber data penelitian adalah buku tematik guru kelas IV tema 3 tentang peduli terhadap makhluk hidup. Metode penelitian menggunakan analisis deskriptif untuk menggambarkan aspek literasi sains. Analisis menggunakan instrumen yang diadopsi dari Chiapetta, Sethna dan Filman di Padayache. Hasil analisis menunjukkan dua temuan penting: 1) aspek ilmu sebagai tubuh pengetahuan yang memiliki persentase tertinggi dari tiga aspek; 2) Tidak semua indikator aspek yang ditemukan dalam buku panduan guru.

Kata kunci: buku guru, literasi sains, analisis kuantitatif, kurikulum 2013.

PENDAHULUAN Buku adalah komponen penting dalam proses pembelajaran. Buku teks atau buku ajar merupakan bahan pengajaran yang paling banyak digunakan diantara semua bahan pengajaran lainnya (Prastowo, 2012). Buku teks selain berfungsi mendukung guru saat melakukan pembelajaran juga merupakan alat bantu bagi siswa dalam menerima materi dari guru. Saat ini buku teks digunakan sebagai bahan utama pada setiap level sekolah (Toharudin,dkk, 2011).

Penggunaan buku pelajaran sains di tingkat sekolah dasar berdasarkan hasil penelitian memiliki posisi yang sangat penting. Buku ajar dijadikan pedoman oleh para guru sains di sekolah dasar dalam proses pembelajaran sains, baik di kelas maupun untuk pemberian pekerjaan rumah yang harus dikerjakan oleh peserta didik. Sejalan dengan itu secara khusus Stinner (1994) mengatakan bahwa membicarakan buku teks berarti membicarakan sesuatu yang mendasar, nyata dan berat. Pendapat Stinner ini sejalan dengan beberapa ahli lainnya (Yager, 1983; Wheatley, 1991; Yore,1991; Kyle, 1992) yang menyatakan bahwa buku teks untuk pengajaran sains memiliki peran yang dominan dan esensial berkenaan dengan cara pengajaran sains (Toharudin,dkk, 2011).

Dalam memilih buku, guru harus mempertimbangkan berbagai faktor. Salah satunya adalah aspek literasi sains. Kemampuan literasi sains sangat diperlukan dalam dunia 
yang dipenuhi dengan produk-produk kerja ilmiah dan teknologi. Literasi sains dapat dipergunakan dalam memecahkan masalah yang menuntut ketrampilan tingkat tinggi, berpikir kreatif, dan inovatif. Rendahnya kandungan literasi sains dalam buku diduga merupakan penyebab rendahnya kemampuan litearsi sains penggunanya dalam hal ini guru dan peserta didik (Firman, 2007; Adisenjaya, 2009).

Saat ini dengan diterapkannya kurikulum 2013, pemerintah membuat dua buah buku yang akan digunakan dalam proses pembelajaran yaitu buku siswa dan buku panduan guru. Buku panduan guru diterbitkan untuk memberi arah dan paradigma yang benar dalam proses pembelajaran kurikulum 2013. Seorang guru haruslah memahami aspek literasi sains terlebih dahulu sebelum pelaksanaan proses pembelajaran, karena penguasaan tingkat literasi sains ternyata berpengaruh terhadap proses mengajar guru di kelas. Oleh karenanya penulis tertarik untuk melakukan penelitian melalui studi analisis deskriptif buku guru tema 3 Peduli terhadap Makhluk Hidup.

\section{METODE}

Metode yang akan digunakan dalam penelitian ini adalah metode studi analisis deskriptif Isi buku.Analisis isididefinisikan sebagai suatu teknik penelitian ilmiah yang ditujukan untuk mengetahui gambaran karakteristik isi dan menarik inferensi dari isi. Analisis ini ditujukan untuk mengidentifikasi secara sistematis isi komunikasi yang tampak, dan dilakukan secara objektif, valid, reliable dan dapat direplikasi (Eriyanto, 2011). Instrumen yang digunakan diadopsi dari lembar observasi yang berisi indikator literasi sains yang digunakan oleh Chiappetta, Fillman \& Sethna (2004) dalam Padayache (2012). Instrumen ini selanjutnya dimodifikasi agar tepat untuk digunakan dalam menganalisis buku panduan guru.

Alur penelitian yang dilakukan digambarkan dalam grafik berikut:

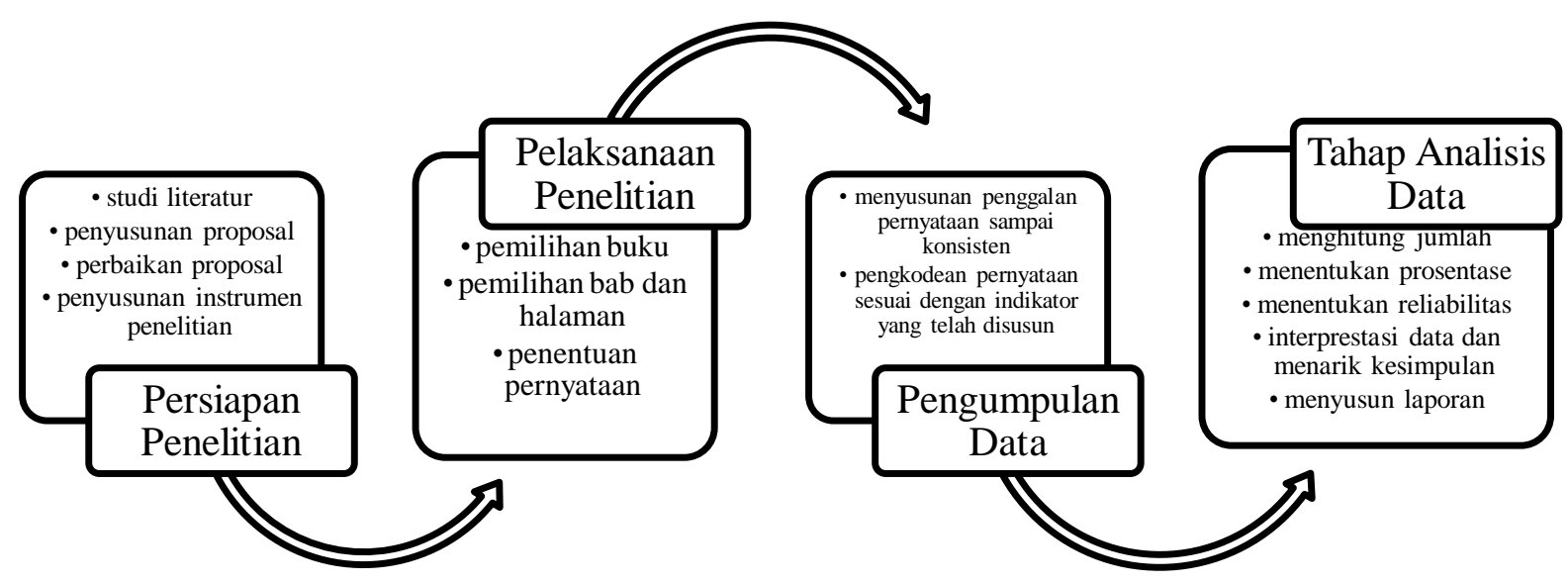

Gambar 1. Alur Penelitian

\section{HASIL DAN PEMBAHASAN}

Analisis dilakukan oleh 3 orang dengan menggunakan metode yang sama. Hal ini dilakukan untuk menghindari hasil yang bias.
Peneliti juga melakukan pemenggalan pernyataan dan pengkodean secara berulangulang sampai di dapatkan hasil yang konsisten. Hasil analisis disajikan dalam tabel berikut:

Tabel 1. Jumlah dan Persentase Panduan Pembelajaran Aspek Literasi Sains pada Buku Guru Tema 3 Peduli terhadap Makhluk Hidup 


\begin{tabular}{|c|c|c|c|c|c|c|c|c|c|c|c|}
\hline \multirow{3}{*}{ No } & \multirow{3}{*}{$\begin{array}{l}\text { Aspek Literasi } \\
\text { Sains }\end{array}$} & \multicolumn{8}{|c|}{ Subtema } & \multirow{3}{*}{ Jumlah } & \multirow{3}{*}{$\begin{array}{c}\text { Persen } \\
\text { (\%) }\end{array}$} \\
\hline & & \multicolumn{2}{|c|}{1} & \multicolumn{2}{|c|}{2} & \multicolumn{2}{|c|}{3} & \multicolumn{2}{|c|}{4} & & \\
\hline & & $\Sigma$ & $\%$ & $\sum$ & $\%$ & $\sum$ & $\%$ & $\sum$ & $\%$ & & \\
\hline 1 & $\begin{array}{l}\text { Sains sebagai batang } \\
\text { tubuh }\end{array}$ & 71 & 25 & 36 & 13 & 24 & 8 & 4 & 1 & 125 & 44,2 \\
\hline 2 & $\begin{array}{l}\text { Sains sebagai jalan } \\
\text { investigasi }\end{array}$ & 23 & 8 & 31 & 11 & 9 & 3 & 12 & 4 & 75 & 26,5 \\
\hline 3 & $\begin{array}{l}\text { Sains sebagai jalan } \\
\text { berpikir }\end{array}$ & 9 & 3 & 9 & 3 & 14 & 5 & 10 & 4 & 42 & 14,8 \\
\hline 4 & $\begin{array}{l}\text { Interaksi sains } \\
\text { teknologi dan } \\
\text { masyarakat }\end{array}$ & 13 & 5 & 11 & 4 & 5 & 2 & 2 & 1 & 41 & 14,5 \\
\hline & & 116 & 41 & 87 & 31 & 52 & 18 & 28 & 10 & 283 & 100 \\
\hline
\end{tabular}

Dari hasil analisis diketahui bahwa aspek sains sebagai batang tubuh masih cukup tinggi dibandingkan ketiga aspek lainnya, artinya pada buku guru ini masih didominasi tentang proses pembelajaran produk-produk ilmu pengetahuan terutama fakta dan konsep. Setiap Aspek mempunyai indikator masing-masing yang disajikan dalam bentuk angka dan huruf. Misalnya 1a menunjukan aspek nomor satu yaitu sains sebagai batang tubuh dan indikator a yaitu panduan pembelajaran fakta. Sebaran hasil literasi sains tiap aspeknya disajikan dalam diagram berikut:
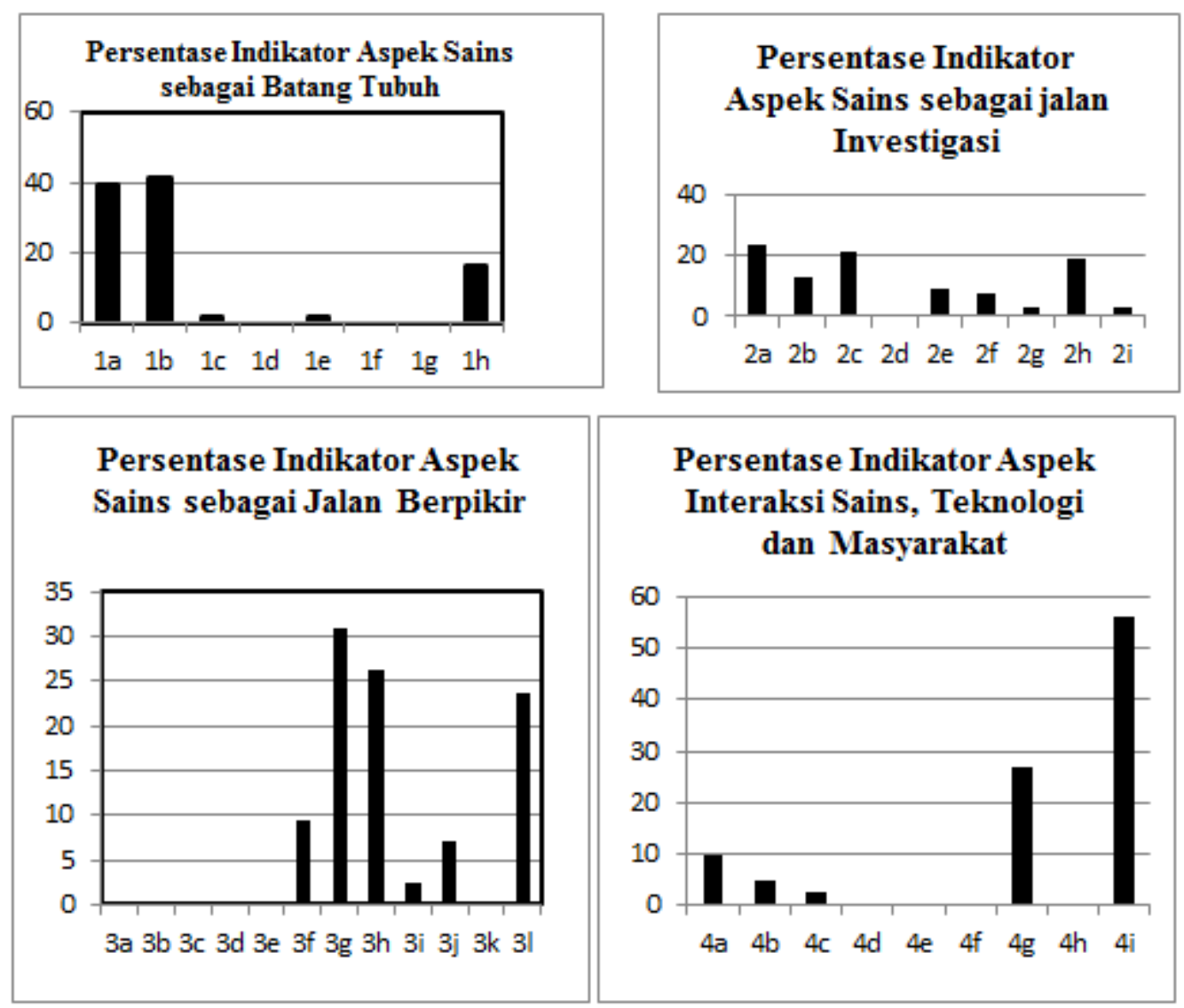

Gambar 2. Diagram Sebaran Hasil Literasi Sains 


\section{Panduan pembelajaran Aspek Sains sebagai Batang Tubuh}

Secara konten, aspek sains sebagai batang tubuh masih mendominasi, buku ini hampir sama dengan buku-buku sains sebelumnya yaitu masih menekankan pada produk, bukan proses sains. Padahal yang diharapkan ketrampilan proses sains yang diharapkan lebih banyak muncul. Terutama aspek sains sebagai jalan berpikir. Walaupun secara kuantitas sudah lebih berkurang dibandingkan dengan penelitian sebelumnya yaitu $80 \%$ untuk aspek sains sebagai batang tubuh (Adisenjaya, 2009).

Panduan pembelajaran fakta dan konsep yang banyak muncul dalam buku panduan guru diantaranya tergambar dalam proses mengamati, dan saling berdiskusi. Contoh " siswa mengamati bagain tubuh merpati yang terdapat di buku siswa" (buku guru halaman 8) dan "siswa mengamati gamabar yang terdapat dalam buku siswa dan menjawab pertanyaan". (Buku guru halaman 24)

"Kemudian secara berpasang-pasangan, mereka mendiskusikan jawaban mereka"(buku guru halaman 24).

Metode eksperimen yang menuntut siswa menyampaikan hipotesis masih sangat sedikit jumlahnya. Hanya ada 1x eksperimen dari $24 x$ pertemuan. Percobaan yang dilakukan adalah mengenal fungsi batang sebagai Penyalur Air dan Mineral (Buku Guru halaman 31). Eksperimen lain yang mungkin disajikan berkaitan dengan fungsi-fungsi bagian-bagian tumbuhan adalah fungsi daun sebagai tempat mengolah makanan melalui proses fotosintesis (eksperimen Sach).

Panduan pembelajaran penyampaian hipotesis terdapat dalam buku guru halaman 32 . Panduannya sebagai berikut:

"sebelum kegiatan percobaan dilakukan, siswa menuliskan hipotesis mereka. Siswa mendiskusikan hipotesis mereka secara berpasangan serta menjelaskan alasan mengapa mereka membuat hipotesis tersebut".

Berdasarkan hasil penelitian sebelumnya kegiatan hands-on dapat memberikan pengalaman langsung bagi siswa dan juga merupakan kunci bagi hubungan antara ketrampilan proses baik dalam sains maupun dalam kegiatan membaca (Lucas \& Burlando, 1975) .
Santrock (2002) menjelaskan bahwa untuk mempertahankan sebuah informasi, pengulangan merupakan sebuah strategi yang dapat dilakukan. Dalam hal ini digambarkan dengan indikator memberikan pertanyaan untuk mengingat kembali informasi yang telah diterima. Panduan pembelajaran ini juga masih sangat minim, hanya muncul dalam beberapa pernyataan diantaranya ,"Ketika siswa bekerja, guru mengajukan pertanyaan-pertanyaan yang memancing siswa untuk melihat kembali hewan yang diamati sebelumnya secara mendetail" (buku guru halaman 14).

\section{Panduan Pembelajaran Aspek Sains Sebagai jalan Investigasi}

Dari grafik diatas dapat disimpulkan semua indikator aspek sains sebagai jalan investigasisudah muncul kecuali indikator pembelajaran membuat kalkulasi. Hal ini disebabkan karena tidak adanya materi sains yang mengharuskan siswa untuk berhitung.

Pembelajaran yang mengikutsertakan media pembelajaran grafis (sketsa, gambar, foto, diagram, dan tabel) akan jauh lebih baik dalam menyimpan daya ingat siswa daripada hanya berupa teks tanpa ilustrasi. Menurut Levine 1982 dalam Toharudin (2011) penyedian gambar pada teks memiliki fungsi antara lain : (1) menarik perhatian; (2) mempertinggi kesukaan;(3) mempengaruhi emosi dan sikap; (4) memberi kemudahan mempelajari teks; (5) memperbaiki pemahaman dan retensi membaca yang lemah.

Dalam buku guru petunjuk untuk membelajarkan siswa melalui tabel, grafik atau gambar sudah cukup terfasilitasi. Contoh penyajian gambar, tabel, dan grafik. "Siswa mengamati bagian tubuh merpati dan melengkapi tabel yang telah disediakan" (Buku guru halaman 8). 


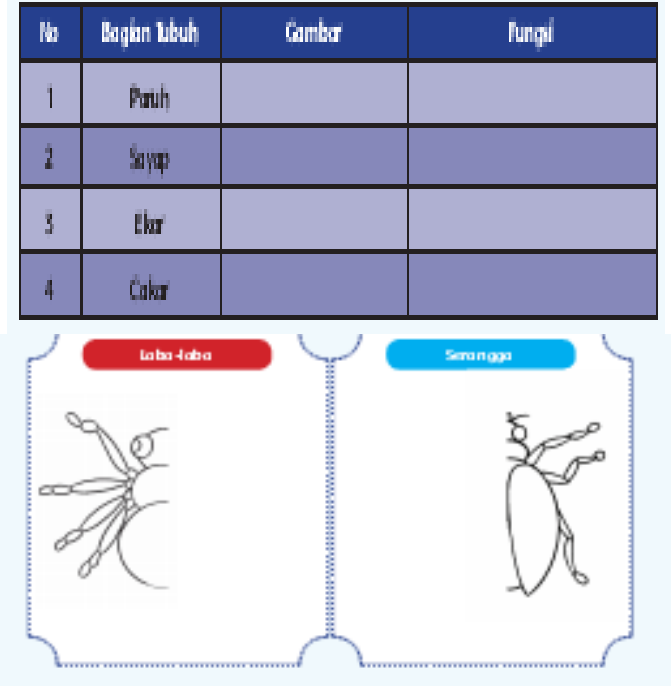

"Siswa melengkapi gambar dan tabel di buku siswa setelah melakukan pengamatan terhadap labalaba dan serangga yang mereka bawa dari rumah " (Buku guru halaman 12).

Tingkatan kemampuan/kompetensi yang diharapkan dari peserta didik baru sebatas mengisi atau melengkapi baik tabel, gambar ataupun grafik. Kompetensi lain yaitu peserta didik diminta untuk mengajukan dan menjawab pertanyaan dengan mengamati tabel. (Buku guru halaman 19) .

Bagian aktif dari proses inquiri adalah memberikan alasan atau argumen berdasarkan hasil eksperimen, observasi, hukum dan teori. (Padayache, 2012). Ketika peserta didik sudah dapat menerangkan alasan-alasan dari jawabannya, maka dia sudah memahami apa yang telah diperolehnya dalam proses pembelajaran berdasarkan proses inquiri. Beberapa proses yang menunjukan bagaimana guru membelajarkan siswa agar dapat menerangkan jawaban tercermin dalam pernyataan berikut.

"Siswa mampu menuliskan alasan mengapa hasil pengamatan pada nomor 2(penilaian proses percobaan fungsi batang) terjadi" (Buku guru halaman 33).

Prinsip pembelajaran pada kurikulum 2013 menyatakan bahwa guru bukan satu satunya sumber belajar. Sumber belajar tidak terbatas dari guru, atau buku saja, apalagi dengan era teknologi sekarang ini dimana internet dapat memberikan informasi apapun yang diperlukan. Guru seharusnya lebih mempunyai wawasan dibanding peserta didik. Buku pegangan guru bisa memotivasi guru untuk mencari sumber sumber lain. Buku guru dapat mempermudah dengan menyedikan link-link yang berkaitan dengan materi. Buku-buku sains dari pengarang luar negeri biasanya sudah menyediakan web link. Misalnya untuk materi morfologi tumbuhan dan fungsinya beberapa link yang berkaitan adalah The biology Place for BIOLOGY, fifth edition di http://www.biology.com/campbell.

Dalam buku guru tema 3 indikator ini sangat sedikit sekali, hanya muncul 2 pernyataan, dan berupa informasi yang diambil dari internet, bukan link lain yang dapat digali oleh guru. Beberapa contoh yang memberikan informasi dari internet.

Siklus hidup tanaman padi dibagi ke dalam tiga fase, yaitu:

1. Vegetatif (awal pertumbuhan hingga pembentukan bakal malai)

2. Reproduktif (bakal malai hingga pembungaan)

3. Pematangan (pembungaan hingga gabah matang)

Bagi siswa, prosesnya adalah sebagai berikut.

Pertumbuhan tanaman padi dibagi ke dalam tiga fase, yaitu:

1. Benih (biji)

2. Benih berkecambah hingga muncul ke pemukaan. Bakal akar dan tunas menonjol keluar, lalu batang memanjang.

3. Berbunga hingga gabah matang, berkembang penuh, danbenvama kuning. Gabahadalah bijiyang terbungkus dalam sekam.

Tahap pertumbuhan padi berlangsung antara 110 hingga 130 har

Sumber: http://umu.litbang.deptan.go.id

(Buku guru halaman 84)

Pendekatan pembelajaran yang disarankan dalam kurikulum 2013 adalah pendekatan saintifik. Pemahaman tentang pendekatan saintifik seharusnya diberikan dalam buku guru. 
Kegiatan yang sering muncul adalah proses pengamatan, mengajukan pertanyaan, melakukan klarifikasi, berdiskusi, menggali informasi lebih jauh, serta menyajikan hasil diskusi (mengkomunikasikan) serta membuat kesimpulan. Hal ini diantaranya terdapat dalam buku guru halaman 15, 19, 57, 64, 65, dan 142 .

Menganalisis dan menginterpretasi merupakan kemampuan yang harus dikembangkan kepada peserta didik. Kehilangan kemampuan ini akan menyebabkan peserta didik kehilangan proses inquirinya. Dalam buku guru tema 3 proses menganalisis ini terdapat dalam subtema 4, dimana dalam buku siswanya tidak ada subtema 4. Kegiatan dalam subtema ini merupakan kegiatan alternatif. Disini guru juga dituntut untuk kreatif dalam menyiapkan proses pembelajaran. Hal ini juga dapat dijadikan proses evaluasi kegiatan pada 3 subtema sebelumnya.

Contoh proses menganalisis dalam buku guru tema 3

"Menanyakan dan menganalisis. Dengan menggunakan data sebelumnya, guru mengajak siswa untuk mempertanyakan dan menganalisis fakta yang ada, misalnya: -Apakah warna kupu-kupu akan sama dari jenis ulat yang sama? (Buku guru halaman 144) terdapat juga pada halaman 145.

\section{Panduan Pembelajaran Aspek sains Sebagai jalan Berpikir}

Berdasarkan hasil analisis aspek sains sebagai jalan berpikir mempunyai persentase sangat kecil dibandingkan ketiga aspek lainnya. Padahal ketrampilan berpikir sebagai sebuah aspek kecakapan hidup harus dibelajarkan sejak dini. Dalam aspek ini terlihat beberapa indikator yang tidak muncul, yaitu pembelajaran sains melalui penjelasan bagaimana ilmuwan bereksperimen, penjelasan perkembangan historis sebuah ide, penjelasan sifat empiris dan objektivitas sains, penjelasan penggunaan asumsi-asumsi, pembelajaran sains melalui proses deduktif dan induktif serta penjelasan karakteristik ilmuwan.

Salah satu aspek yang banyak diabaikan dalam proses pembelajaran padahal dapat membantu proses berpikir siswa adalah kurang memberi informasi kepada peserta didik mengenai sejarah sains. Guru maupun buku kurang memberi penjelasan tentang upaya dan langkah yang ditempuh oleh seorang ilmuwan dalam menemukan suatu konsep, hukum, teori atau penemuan lainnya yang berbentuk barang, seperti sepeda, pesawat, telepon, mesin uap komputer dan lain sebagainya. Padahal, sejarah penemuan dan upaya para ilmuwan tersebut, jika disampaikan kepada peserta didik, akan menjadi masukan yang sangat berarti bagi peserta didik untuk meningkatkan motivasi belajar. Perkembangan ini juga membelajarkan peserta didik tentang pentingnya sebuah proses. Bahwa ilmu pengetahuan tidak akan muncul begitu saja namun harus diawali dengan sebuah proses belajar, berpikir dan berkreasi.

Buku pegangan guru sebaiknya menyertakan aspek ini dengan baik sehingga guru mempunyai wawasan yang lebih untuk disampaikan kembali kepada peserta didik dengan teknis yang dirancang sedemikian sehingga dapat menarik dan bermakna bagi peserta didik. Peserta didik pada jenjang pendidikan dasar mempunyai karakteristik meniru yang sempurna. Pembelajaran dengan menampilkan sosok-sosok ilmuwan diharapkan akan menginspirasi dan memotivasi peserta didik.

Dalam buku ini baik sejarah sains, proses perkembangan ide, sifat empirisme sains masih sangat kurang. Setiap materi sains pasti ada tokoh di baliknya. Seperti misalnya dalam morfologi hewan dan tumbuhan dapat disampaikan bapak Carolus Linneus (1707- 1778) seorang dokter dan ahli botani dari Swedia yang mencari keteraturan di dalam keanekaragaman kehidupan "untuk kemulian dan keagungan Tuhan. Linneus adalah pendiri taksonomi yaitu cabang biologi yang membahas penamaan dan pengelompokan bentuk kehidupan yang sangat beraneka ragam (Campbell, 2003:6).

Sebaiknya dalam buku panduan terdapat pembelajaran yang mengembangkan imajinasi dan kreativitas namun dalam buku guru hanya muncul 3 kali yaitu dalam pernyataan berikut :

"Guru memberi pentunjuk bahwa komentar atau pertanyaan yang diberikan dapat berhubungan dengan kesulitan yang dihadapi saat menjawab pertanyaan atau memberikan masukan untuk teman" (Buku guru halaman 65).

Selebihnya terdapat pada terdapat dalam subtema 4 pembelajaran 1 dan 2. Yaitu dalam pernyataan berikut: "siswa harus mengumpulkan 40 fakta dari hewan yang mereka amati. Setiap siswa boleh mengamati objek yang sama". 
Penjelasan karakteristik seorang ilmuwan tidak muncul dalam tema 3, padahal ketika membelajarkan sikap atau karakter, salah satu metodenya adalah dengan memberikan penjelasan sikap-sikap apa saja yang seharusnya dimiliki oleh seorang ilmuan. Hal ini diharapkan dapat memotivasi peserta didik untuk berbuat seperti yang dicontohkan.

\section{Panduan pembelajaran Aspek Interaksi Sains, Teknologi dan Masyarakat}

Interaksi sains teknologi dan masyarakat merupakan perekat yang mengaitkan sains, teknologi dan masyarakat secara terintegrasi. Pendekatan ini merupakan salah satu alternatif konsep penyempurnaan dan penyesuaian pendidikan sains saat ini. Konsep ini diwujudkan dalam bentuk materi pembelajaran. Interaksi sains teknologi dan masyarakat juga dikembangkan untuk meningkatkan literasi ilmiah individu agar mengerti bagaimana sains, teknologi dan masyarakat, saling berpengaruh satu sama lain, serta untuk meningkatkan kemampuan menggunakan pengetahuan dalam keputusan. Dengan demikian peserta didik dapat menghargai sains dan teknologi dalam masyarakat, dan mengerti keterbatasanketerbatasannya (Yager, 1990).

Berdasarkan hasil analisis aspek ini didominasi penilaian aspek nilai dan sikap dalam sains. Hal ini dikarenakan isu dalam kurikulum 2013 untuk menyeimbangkan antara aspek kognitif, afektif dan psikomotorik. Hal ini juga untuk menjawab paradigma yang selama ini terbangun bahwa pendidikan di kita saat ini hanya memfokuskan pada aspek kognitif saja baik dalam materi, proses pembelajaran dan proses penilaiannya.

Beberapa indikator seperti penjelasan karirkarir dan pekerjaan-pekerjaan di bidang ilmu dan teknologi yang bersangkutan dengan materi belum muncul. Selain itu indikator penjelasan adanya kontribusi terhadap keberagaman serta penjelasan tentang dampak sosial budaya dari sebuah ilmu dan teknologi masih belum ada dalam panduan buku guru. Indikator panduan guru tentang adanya keterbatasan sains juga tidak muncul.

Memaparkan sejak dini pekerjaan-pekerjaan apa saja yang berkaitan dengan materi yang sedang dipelajari akan sangat bermanfaat untuk peserta didik. Hal ini juga dapat memotivasi peserta didik bagaimana nantinya untuk menerapkan ilmu yang di dapatkan. Peserta didik akan lebih termotivasi untuk memahami konsep jika mereka tahu manfaat materi yang sedang dipelajarinya tersebut. Diantaranya adalah menjelaskan keterkaitan materi yang dipelajari dengan pekerjaan-pekerjaan atau karirkarir yang berkaitan.

Prinsip pembelajaran dalam kurikulum 2013 menyatakan bahwa pembelajaran dapat di lakukan di sekolah, di rumah dan di lingkungan. Hal ini sudah diimplementasikan dalam buku siswa dan dipandu dalam buku guru. Dalam buku guru dipandu bagaimana peserta didik dapat melakukan proses pembelajaran di rumah dengan orang tua maupun teman sebaya atau masyarakat sekitar. Jika dalam buku siswa di setiap awal subtema terdapat lembar untuk orang tua yang berjudul "belajar di rumah", sedangkan dalam buku guru terdapat poin kerjasama dengan orang tua disetiap akhir pembelajaran.

Contoh pernyataan dalam buku guru yang merupakan indikator penjelasan proses interaksi kolaborasi dengan masyarakat yaitu:

"Kerjasama dengan orang tua. Siswa mengobservasi hewan yang ada di lingkungan sekitar rumahnya dengan pendampingan orang tua dan mengisi tabel yang terdapat pada buku siswa. Hasilnya dilaporkan kepada guru dan didiskusikan dengan teman satu kelompok"(Buku guru halaman 10).

\section{SIMPULAN}

Buku yang memenuhi aspek literasi sains harus menyatukan semua aspek yang berhubungan dengan sains, termasuk sains sebagai sebuah proses yang diwakili oleh aspek sains sebagai jalan investigasi dan sains sebagai jalan berpikir. Hasil analisis buku pegangan guru berdasarkan literasi sains memberikan dua buah temuan penting yaitu: 1) aspek sains sebagai batang tubuh mempunyai persentase paling tinggi dibandingkan 3 aspek lainnya; 2) tidak semua indikator setiap aspek sains muncul dalam buku pegangan guru.

Simpulan hasil penelitian berdasarkan temuan selama proses penelitian dapat menjawab pertanyaan penelitian yang telah diajukan sebagai berikut: 
1. Penyajian panduan pembelajaran Aspek sains sebagai batang tubuh secara keseluruhan mempunyai porsi yang lebih banyak. Walaupun beberapa indikator tidak tersaji seperti indikator pembelajaran hukum, teori dan model. Ketidak tersajian indikator ini dikarenakan karakteristik dari materi untuk tahap sekolah dasar tidak memungkinkan adanya hukum dan teori. Penggunaan model juga tidak diperlukan karena sumber belajar materi ini sudah tersedia di alam.

2. Penyajian panduan pembelajaran aspek sains sebagai jalan investigasi sudah cukup menyajikan semua indikator kecuali indikator pembelajaran kalkulasi. Terdapat beberapa indikator yang diharapkan lebih banyak muncul namun masih sedikit diantaranya pembelajaran yang melibatkan peserta didik untuk melakukan ekperimen dan panduan untuk mendapatkan informasi dari internet.

3. Penyajian panduan pembelajaran aspek sains sebagai jalan berpikir mempunyai presentase yang masih sedikit. Masih banyak indikatorindikator yang seharusnya ada namun belum muncul. Diantaranya indikator panduan bagaimana seorang ilmuwan melakukan eksperimen, sejarah perkembangan ide, sifat empiris dan objektif, penggunaan asumsiasumsi, penjelasan induktif dan deduktif, karakteristik ilmuwan dan alternatif memahami alam semesta. Aspek sains sebagai jalan berpikir masih sangat minim sehingga harus lebih diperhatikan kembali.

4. Penyajian panduan pembelajaran aspek interaksi sains teknologi dan masyarakat juga masih sangat sedikit. Aspek ini sebenarnya merupakan aspek aplikasi dan sikap sains. Seharusnya diharapkan dapat lebih banyak tersaji. Indikator-indikator seperti penjelasan karir atau pekerjaan, kontribusi terhadap keberagaman, dampak sosial budaya dari ilmu sains dan teknologi serta penjelasan keterbatasan sains tidak muncul. Indikator lain juga walaupun sudah ada namun porsinya masih sangat sedikit, misalnya indikator panduan diskusi masalah-masalah sosial yang berkaitan dengan sains dan teknologi.

\section{REFERENSI}

Adisendjaja, H Y. (2009). Analisis Buku Ajar Biologi SMA Kelas $X$ di Kota Bandung Berdasarkan Literasi Sains. Skripsi. tidak diterbitkan. Bandung: FMIPA UPI.

Campbell, N., Jane B R., Lawrence G.M. (2003). Terjemahan Biology (Edisi kelima jilid 1). Jakarta: Erlangga.

Chiappetta, E.L, Fillman, D.A, \& Sentha, G. H. (1991). "A Method to Quality Major Themes of Scientific Literacy in Science Textbooks". Journal of Research in science teaching. 28, (8), 713-725

Chiappetta, E.L, Fillman, D.A, \& Sentha, G. H. (1991). "A Quantitative Analysis of High School Chemistry Textbooks for Scientific Literacy Themes and Expository Learning Aids" Journal of Research in science teaching. 28, (10), 939-951.

Collette, A. T \& Chiappetta. E L (1994). Science Instruction In The Middle and Secondary Schools. New York: MacMillan Publishing.

Eriyanto. (2011). Analisis Isi: Pengantar Metodologi Untuk Penelitian Ilmu Komunikasi dan Ilmu ilmu soaial Lainnya. Jakarta: Kencana Prenada media Group.

Firman. (2007). Analisis Literasi Sains Berdasarkan Hasil PISA Nasional Tahun 2006. Jakarta: Pusat Balitbang Depdiknas.

Kementrian Pendidikan dan Kebudayaan Republik Indonesia. (2013). Tema 3 Peduli terhadap Makhluk Hidup. Buku Tematik Terpadu Kurikulum 2013. Buku Guru SD/MI Kelas IV. Jakarta: Lazuardi GIS dan Politeknik Negeri Media Kreatif.

Lucas, S. B \& Burlando, A.D. (1975). The new science methods and reading. Languange Art 52.

Padayachee, K. (2012). A study on the Aalysis and Use of Life Sciences Textbooks for the Nature of Science. Dissertation. Online diakses tanggal 10 Desember 2013.

Prastowo, A. (2013). Pengembangan Bahan Ajar Tematik Panduan lengkap Aplikatif. Jogjakarta : Diva Press.

Santrock, J.W (2002) Life span Development. Perkembangan Masa Hidup(terjemahan jilid I Edisi kelima). Jakarta: Erlangga.

Toharudin, U. dkk. (2011). Membangun Literasi Sains Peserta Didik. Bandung: Humaniora.

Yager, R. (1990). The Science/Technology/Society Movement in the United States;Its Origin, Evolution, and Rationale. Tanpa kota: Social Education. 